$$
\text { Prugberger Tamás }
$$

\title{
A facere típusú szerződések alakulása a gazdasági társasági jogalanyiság módosulása tükrében
}

\section{Development of Facere-type Contracts in the Light of the Changes in Corporate Legal Personality}

\section{Összefoglalás}

Az új magyar Ptk. a közkereseti és a betéti társaságot is jogi személynek minősítette. Ezért a velük - mint kisvállalkozásokkal - kötött tartós vállalkozási, valamint megbízási szerződések nem minősülnek munkaviszonynak annak ellenére, hogy ha pl. alvállalkozóként fővállalkozó számára építkezésként, vagy egy termékgyártó cégnek tartós beszállítóként alkatrészeket gyártanak, gyakran a munkavállalói jogviszonyhoz hasonlóvá válik alárendelt helyzetük. A tartós vállalkozási és megbízási szerződésnél alkalmazott hagyományos vállalkozási és megbízási jogviszony ugyanis elsősorban a megrendelő és a megbízó érdekeit védi és nem a vállalkozóét, valamint a megbízottét, mely utóbbiakét az egzisztenciális függetlenség és az ügyfélkör korlátlansága védi. Ez az egzisztenciális függetlenség és ügyfélkör korlátlanság a tartós vállalkozási és megbízási jogviszonynál nem áll fenn, ezért helyzetük kiszolgáltatott. Ez azzal volna megszüntethető, ha a tartós vállalkozás és megbízás elszakadna az alapszerződéstől, „sui generis” szerződéssé válna.

Kulcsszavak: alárendeltség, alvállalkozás, fơvállalkozás, jogi személyiség, közkereseti és betéti társaság, tartós vállalkozási és megbízási jogviszony

Prof. Dr. Prugberger Tamás DSa, professor emeritus, Miskolci Egyetem, (prugberger.tamas@t-online.hu). 
Prugberger Tamás: A facere típusú szerzódések alakulása a gazdasági társasági jogalanyiság ...

\section{Summary}

The new Hungarian Civil Code has classified limited partnership and general partnership as legal entities, too. Therefore, long-term business and agency contracts concluded with them, as small businesses, do not qualify as employment relationships, even though, for example, when they manufacture components as a subcontractor for a main contractor in the construction industry, or as a permanent supplier for a manufacturer, their subordinate position often becomes similar to that of an employee. Namely, the traditional business and agency relationship applied in long-term business and agency contracts primarily protect the interests of the customer and the principal and not those of the contractor or the agent, whose interests are protected by existential independence and unlimited clientele. Existential independence and unlimited clientele do not exist in the case of long-term business and agency relationships; therefore, their status is vulnerable. This situation could be solved if permanent business and agency became detached from the basic contract and became a "sui generis" contract.

Keywords: subordination, subcontracting, main contractor, legal personality, general partnership and limited partnership, long-term business and agency relationship

\section{ProblémAEXPONÁLÁS}

A tanulmány két kérdéskörre koncentrál. Az egyik a Szladits Károly által szintetizált hagyományos magánjogon belül a vállalkozóként és munkáltatóként egyaránt megjelenő és az 1959. évi IV. tv.-el megalkotott első Polgári Törvénykönyvben a többszöri és átfogó módosítások ellenére jogi személyiség nélküli gazdasági társaságoknak az új, második Polgári Törvénykönyvben (2013: V. tv.) jogi személyiséggel felruházott gazdasági társaságokká történt átalakítása. A másik a munkatevékenységgel, valamint az ügyvitellel összefüggő jogügyleteknek a Szladits Károly szerkesztői és Vincenti Gusztáv valamint Villányi Miklós szerzői koncepciója szerinti szélesebb összefüggésen keresztül történő vizsgálata, amely túlmegy a szerződéseken és vizsgálja az e körbe tartozó egyoldalú jogügyleteket is. ${ }^{1}$ E két gazdaság-magánjogi jogterület a gyakorlatban nem egy esetben össze is kapcsolódik egymással, amire főleg beruházásoknál fö-, és alvállalkozói hálózati rendszerek kialakításánál kerül sor. A fővállalkozó ilyen esetekben részvénytársasági (Rt.) vagy korlátolt felelősségủ társasági (Kft.), esetleg szövetkezeti formában múködő nagyobb volumenủ cég, amely a megrendelője számára többrétű feladatteljesítését több alvállalkozóra osztja le, amelyek között közkereseti (Kkt.) és betéti társaságok (Bt.), sőt időnként egyéni cégek és cégbejegyzés nélküli egyéni vállalkozók is találhatók. A cégbejegyzés nélküliek általában a lakóhely szerint illetékes önkormányzati hivatal által kiállított vállalkozási igazolvány birtokában dolgoznak. Közöttük találhatók szép számban olyanok is, akik nem saját számlára, szabad vállalkozókként dolgoznak, hanem látszat vállalkozókként vagy a fơvállalkozó (generálkivitelező), vagy valamely reszortfeladatot ellátó alvállalkozó részére formailag olyan tartós, quasi kényszer al-alvállalkozóként dolgozik az őt foglalkoztató fôvállalkozói vagy alvállalkozói szervezetében, mint azok, akiket munkaviszony formájában foglalkoztat. Teszi 
ezt azért, hogy mentesüljön a munkavállaló egészség-, és nyugdíjbiztosítása után fizetendő havi járulékösszeg munkáltatót terhelő rész megfizetése alól. ${ }^{2}$

Ezek a kérdések ilyen élesen nem merültek fel sem az első, sem a második világháborút megelőző magyar polgári jogi, illetve magánjogi kodifikációs kísérletek során. Probléma csupán az volt, hogy az I. Világháborút megelőző polgári törvénykönyv tervezetekbe, valamint az 1928. évi Magánjogi Törvényjavaslatba (Mjt. jav.) bekerüljön az ipartörvényből a „munkaszabályzati”, másképpen szólva a „kollektív”-, illetve a „tarifaszerződés”, vagy se. Magyarországon ez akkor jogrendszer-tagozódási kérdést nem vetett fel. ${ }^{3}$ Nem úgy, mint a két világháború közötti német munkajogtudományban, ahol Hugo Sinzheimer felvetette, hogy a kollektív szerződés intézményének elismerésével a munkaszerződést indokolt lenne kivenni a Ptk.-ból (BGB) és mind az individuális-, mind pedig a kollektív munkajogviszonyt önálló jogviszonyként kellene kodifikálni. ${ }^{4} \mathrm{Ez}$ a nézet a legújabb magyar jogi irodalomban Kiss Györgynél szintén felmerült (Kiss et al., 2020:91-92. és 2020:277-278) és lényegében ezzel összefüggésben alkotta meg azt a kodifikációs javaslatát a 2012. évi I. tv.-el összefüggésben, hogy a nyugat-európai munkajogi szabályozáshoz hasonlóan az olyan önfoglalkoztatót, aki nem a saját, hanem a foglalkoztatója számlájára dolgozik, „munkavállalóhoz hasonló személynek" kell tekinteni. Ez annyit jelentene, hogy esetükben az individuális és kollektív munkajogi szabályokat, vagy közülük legalább is azokat, amelyek a munkavállalók egzisztenciális és szociális biztonságát védik, reájuk is alkalmazni kell. ${ }^{5}$

\section{A kÖZkereseti (KKT.) És a betéti (BT.) TÁrsaságnak aZ ÚJ PTK-BAN JOGI SZEMÉLYISÉGGEL TÖRTÉNT FELRUHÁZÁSÁNAK A KÉRDÉSE}

A 2013. évi új Ptk. (2013: V.tv.) a hagyományos magánjogi jogi személyiségi elmélettel szemben a közkereseti társaságot (Kkt.) és a betéti társaságot (Bt.) a kereskedelmi forgalom biztonsága érdekében jogi személyiséggel ruházta fel. Mind az első világháborút megelőző két magyar Polgári Törvénykönyv Tervezet, mind azok tökéletesítésével az 1928-ban vitára kiadott Magánjogi Törvényjavaslat (Mjt.) a kereskedelmi társaságok közül csak a részvénytársaságot, a korlátolt felelősségű társaságot (Kft.) és a szövetkezetet ruházta fel jogi személységgel, míg a Kkt.-t és a Bt.-t nem. E két „,merkantilis societas” csupán perképességgel rendelkezett a német jogi megoldáshoz hasonlóan azzal a különbséggel, hogy míg Magyarországon valamennyi itt megjelölt kereskedelmi társaságot az Mjt. magába foglalta, ${ }^{6}$ addig a német BGB csak a jogi személység nélküli első kettőt szabályozta, míg a jogi személyiséggel rendelkező kereskedelmi társaságok valamennyi típusát külön törvényekbe foglalta. ${ }^{7}$ Az 1959. évi magyar Ptk.-ban a kereskedelmi társaságokat érintő e jogalanyiságbeli probléma azért nem mutatkozott meg, mivel a kodifikációjának az időszakában az állam-szocialista gazdasági rendszernek megfelelően az állami vállalat, a szövetkezet és részben a magán kisiparos és kiskereskedő elégítette ki a fogyasztói igényeket kötött „népgazdasági” tervezési rendszer keretében. Az 1970-es évek közepén megindult gazdaságirányítási reform hatására a Sárközy Tamás által elkészített és 1982. évi VI. tv.-el hatályba lépett első, majd 1984-től ugyancsak a tőle származó második Gazdasági Társasági Törvény (Gt.) a jogalanyiság kérdését mindenképpen az Mjt-hez hasonlóan szabályozta a kereskedelmi társaságoknak gazdasági társaságokká átkeresztelve e négy típusát. ${ }^{8}$ 
A Kkt.-nek és a Bt.-nek jogi személyiséggel történő felruházása a forgalom biztonsága és zökkenőmentes lebonyolítása szempontjából mindenképpen előnyös lépés volt, amire magam is tettem javaslatot a „Disserationes Savariensis” kiadványsorozat 2002-ben megjelent 16. sz. füzetében (Prugberger et al., 1997:20-26). Annak érdekében, hogy a Kkt.-t és a Bt.-t jogi személynek el lehessen ismerni, bizonyos mértékig meg kellett változtatni a jogi személyiség hagyományos tanát. Nem lehetett tovább tartani azt a korábbi elméletet, hogy a jogi személy vagyona és szervezete teljesen elkülönül a tagokétól, amit rugalmasabbá kellett tenni annak kimondásával, hogy csak az alapítójától elkülönült vagyonnal kell rendelkeznie és azt sem kell kimondani, hogy az ügyvezetését és képviseletét ellátó szervezete a tagoktól teljesen elkülönítve, tőlük függetlenül működik (Ptk. 3: 2. § 5. bek.). Csak így hozható összhangba a Kkt. valamennyi tagjának és a Bt. valamennyi beltagjának azzal az egyetemlegesen fennálló kötelezettségével, hogy helytállni tartozik a társaságnak a társasági vagyon által nem fedezett tatozásaiért. A Tagok és a beltagok ugyanis a társaságnak a társasági vagyon által nem fedezett kötelezettségeiért korlátlanul és egyetemlegesen kötelesek helytállni.

Mint már szó esett róla, ez a szabály a forgalom biztonsága és zökkenőmentes lebonyolítása érdekében jött létre, csak úgy, mint a jogi személy lépcsőzetesen és hierarchizáltan tagolt elmélete, amely azt demonstrálja, hogy egy magasabb jogi személyiséggel felruházott szervezeti egységen belül lefelé irányulva azonos és különböző szinteken az adott szervezet a benne lévő szervezeti egységeket vagyon-elkülönítés mellett jogi személyiséggel ruház fel. ${ }^{9}$ Tágabb értelemben beszélhetünk osztott és lépcsőzetes jogalanyiságról is, ahol nemcsak jogi személynek minősülő társas cégek, hanem társas cégnek nem minősülő egyéni-családi cégek, vállalkozások is szerepelhetnek, amelyek közül a többség nem jogi személy, de közöttük egyszemélyes Rt. vagy Kft. is lehet, amely viszont jogi személy. Ilyen lehet akár egy szervezeten belül elkülönített vagyonnal rendelkező egyszemélyes vagy csoportos átalány-elszámolási egység (gebin), amely legtöbbször nem jogi személy, hanem természetes személyiségű jogalany (Prugberger et al., 1989:38-47; 1989:50-80). Ilyen vagy hasonló jellegű helyzet bekövetkezhet tőzsdei jogügyletek útján is, amikor egy cég egy vagy több cég részvényeinek a megvásárlásával részvénypakettet megszerezve saját szervezetébe jogi személyiség megadásával betagolja, vagy formálisan önálló, de szolgáló vállalatként meghagyva határozza meg annak működését. Egy cég egy másik céget azonban a tőzsdén kívül is megvásárolhat úgy, hogy jogi önállóságát is elvonva teljesen betagolja a maga szervezetébe, de megtartva formális önállóságát -szatelit vállalataként tartósan bedolgozó-beszállítójaként vagy alvállalkozójaként foglalkoztatja. Ha az ily módon szolgálóvá vált társas cég látszólagos önállóságát megtartva, tartós bedolgozójává válik a végső termékösszeállítást elvégző termékkibocsátó cégnek, szerződéses integrációba kerül vele tartós vállalkozói szerződés formájában. Azonban gyakori az ügyvitelnek és a jogi képviseletnek is ilyen kiszervezése bizalmi alapon könyvelői társaság vagy jogiroda részére, amikor is tartós megbízási, ügyviteli szerződés létesül a felek között. Az is előfordul, hogy az uralkodó vállalatok mintegy szolgáló vállalti forma keretében tartós vállalkozási és/vagy megbízási jogviszonyt létesítve foglalkoztatnak önálló vállalkozókat és iparszerű ügyvitelt végző személyeket. Ha az ilyen szabadfoglalkozású önfoglalkoztató személyek nem a saját számlájukra és veszélyükre, hanem a foglalkoztatójuk számlájára és veszélyére végzik a munkát, azt csak formális kényszervállalkozási és/vagy megbízási jogviszonyban tehetik, mivel foglalkoztatók a 
foglalkoztatottjaik után nem akarják a kötelező nyugdíj-, és egészségbiztosítás megkötését követő járulékfizetésnél a munkáltatót terhelő részt viselni. Ha pl. egy építkezésen a fővállalkozó alvállalkozóinak egyike vagy másika így foglalkoztat quasi saját alvállalkozójakén személyeket, minden további nélkül megteheti. Ez a fővállalkozóra semmiféle kötelezettséget nem hárít. Ugyanakkor, ha az ilyen kényszer „al-al vállalkozó” a munkavégzés során megsérül, kiszolgáltatott helyzetbe kerülhet, különösen akkor, ha a sérülés a fővállalkozó hibájából történt. A fóvállalkozó az alvállalkozóval megegyezhet úgy, hogy az „al-alvállalkozô”’ sérelmére állítsák be az ügyet úgy, hogy nem következett be üzemi baleset. Minél több az áttétel, annál nagyobb ennek a veszélye. Mindez amellett szól, hogy helytálló lett volna, ha a 2012. évi I. törvénnyel hatályba léptetett új Mt. 3. §-ába bekerült volna az a szabály, hogy aki formálisan vállalkozói, vagy megbízási jogviszony keretében a munkavállalóhoz hasonló tevékenységet folytat egy foglalkoztató részére, az munkavállalóhoz hasonló személynek minősülve a nyugat-európai államokhoz hasonlóan élvezze a munkajogviszonyból adódó munkavállalót egzisztenciálisan és szociálisan védő minimál standardokból álló kedvezményeket. ${ }^{10}$

Itt azonban meg kell jegyezni, hogy a munkavállalóhoz hasonlóan más érdekében függő munkavégzésben tevékenykedő önfoglalkoztatóhoz hasonló helyzetben lehet egy olyan egyéni,családi cég és/vagy társas kisvállalkozás, amely felett egy fővállalkozó, vagy alvállalkozó áll és a jogviszony majdnem olyan fölé-alárendelt helyzetű, mint amilyen az itt említett önfoglalkoztató jogviszonya. Nem véletlen, hogy a közép-európai régió posztkommunista államainak európai uniós tagokká válásával nem került kiterjesztésre e régió államaira az önfoglalkoztatásról szóló 86/613. sz. irányelv, sőt a 2010/4. sz. irányelvvel hatályon kívül helyezésre is került. Ennél fogva nemcsak, hogy nem volt kötelező figyelembe venni a közép-európai országokban a hatályon kívül helyezett irányelvet, hanem éppen az ellenkezőjét várta el az új tagállamoktól az Európai Unió. Vagyis azt, hogy az új tagállamokban a kényszervállalkozási és/vagy megbízási jogviszonyban dolgozó, saját kötelező társadalombiztosítási járulékaikat egyedül fizető dolgozókra a munkajogviszony egzisztenciális és szociális védő szabályai ne terjedjenek ki. Ugyanakkor a régi tagállamok esetében a munkavállalókhoz hasonlóan dolgozókra a régi tagállamokban most is változatlanul érvényesülnek az immár tíz éve hatályon kívül helyezett irányelv rendelkezései.

A nyugat-európai államok munkajoga jogalkotási szinten is az egyéni vállalkozói tevékenységek között különbséget tesz aszerint, hogy az iparszerüen vállalkozói tevékenységet folytató, valamint megbízások intézését felvállaló személyek a megrendelőiktől és/vagy megbízóiktól gazdaságilag függetlenek vagy függő jogviszonyban állnak és ha igen, az mennyiben jelent személyi függőséget is. Ha személyi függőség is valamilyen formában fennáll a megrendelőtől vagy a megbízótól, akkor már munkavállalóhoz hasonló helyzetről van szó. Ez áll fenn akkor, ha az ilyen személy nem a saját számlájára és veszélyére, hanem az őt foglalkoztató számlájára és veszélyére dolgozik. Ez esetben, ha a tevékenysége során az ilyen foglalkoztatott formális vállalkozó, vagy megbízott az ügyfélnek kárt okoz, a foglalkoztatójának kell helyt állnia. Ugyanis a szerződést a foglalkoztatójával, nem pedig azzal kötötte meg, akinek a kárt okozta. Jóllehet, az önfoglalkoztatás és a munkavállalóhoz hasonló személy intézménye a nyugat-európai jogokban a természetes személyek munkavégzéssel összefüggő jogügyletkötéseinél biztosít védelmet, ami azonban kiterjedhet olyan többalanyú munkavégzésre is, amikor 
a munkát végzők a foglalkoztató számára csoportban dolgoznak, azonban a csoportnak nincs jogi személyisége. Ez áll fenn a legtöbb államban nemcsak a polgári jogi társaság vagy munkaközösség keretében folyó munkánál, hanem az olyannál is, ahol azt Kkt. vagy Bt., vagy esetleg családi vállalkozás keretében végzik. A nyugat-európai államokban azok, akik ilyen szervezeti keretek között csoportosan vagy megosztva, de közösen végzik a munkát, védve vannak, mert munkavállalókhoz hasonló személyeknek minősülnek. Az új Ptk. szerint azonban ez a védelem már a Kkt. és a Bt. esetében már nem áll fenn, mert ez a két társasági forma jogi személlyé vált. E két szervezeti keretben dolgozók az oroszországi megoldáshoz hasonlóan csak szakszervezetbe történő belépéssel juthatnának védelemhez, ahol a kisvállalkozások az ágazati tevékenységüknek megfelelő szakszervezetekhez csatlakozva részesülnek jogi védelemben. ${ }^{11}$

Hasonló problémák azonban a normális cégszerűen működő egyéni-családi és a társasági formák közül nemcsak a Kkt. és Bt. formában működő, hanem a kis taglétszámú Kft-ék és szövetkezetek esetében is fennállhat, főleg olyankor, amikor egy nagyvállalkozás számára alvállalkozóként, vagy tartós szatelit vállalkozásként bedolgozói tevékenységet folytatnak. Ilyen esetekben hasonló tartós vállalkozási, alvállalkozási, vagy megbízási jogviszonyok alakulhatnak ki, amelyeknél a szolgáltató kis-, esetleg középvállalkozás a megrendelő fővállalkozó, öszszeszerelő foglalkoztató céghez viszonyítva alárendelt, nem egyszer kiszolgáltatott helyzetben van. Jogi védelmük már csak a forgalom biztonsága miatt is fontos. Ugyanis egy profitéhes tartósan foglalkoztató fóvállalkozó cég egy neki bedolgozó és vele kiszolgáltatott alvállalkozói helyzetben álló céget tönkre tehet, amiből származó kiesése gazdasági kapcsolati láncolatokat zavarhat meg és a munkaerőpiacon a kínálati oldalt terhelheti meg.

Ezek a problémák szociálisan feszítik nemcsak a gazdaságot, hanem a fogyasztók, a szolgáltatást igénylők széles rétegeit is. E kérdés megoldása együtt jelentkezik a nem jogi, hanem a természetes személyek olyan gazdasági és foglalkoztatási szempontból fennálló függő helyzetével, amely munkavállalóhoz hasonlókká kényszeríti őket.

\section{A MUNKAVÁllalóhoz hasonló ÖNFOGLALKOZTATÓ SZEMÉLYEK}

VÉDELME

Európa valamennyi államában, függetlenül attól, hogy nyugati, vagy keleti, vagy pedig középső felében helyezkedik el, főleg germán-német hatásra az állami és a magánbányászatban, valamint az állami pénzverdékben kialakult a bánya-társasládák intézménye, amelyben a munkáltató, vagyis a bányatulajdonos és a bányászok, az utóbbiak öregségük vagy betegségük miatt tartósan vagy átmenetileg munkaképtelenné válásuk esetére a munkáltatói szolidaritással ötvözve közösen létrehozták szolidaritási pénzalapjaikat. E segélyegyletek a bánya-társasládákból nőttek ki, amelybe a bányamunkások megosztva a tulajdonossal általában az alapbér, illetve a vállalati béralap meghatározott százalékát egyenlő arányban havonta folyamatosan befizették. Ez mind a tulajdonosi, mind pedig a munkavállalói oldalt általában feles arányban terhelte. Ez először az állami tulajdonban álló cégeknél alakult ki, amelyek nehézipart működtették abból az elvből kiindulva, hogy a munkáltatót gondoskodási kötelezettség (Fürsorgepflicht) terheli a munkavállalójával és családjával szemben. Mindez betegsége esetén abban mutatkozott meg, hogy felgyógyulásáig, legfeljebb azonban hat hétig betegszabadságon van és ez alatt 
az idő alatt a munkáltatótól az átlagkeresetét kapja meg. A betegszabadságra járó összeg, az előbb említett segélyládába - a munkáltató és a munkavállalók által - történt befizetésekből tevődött össze. Addig, amíg a bissmarki kötelező társadalombiztosításnak mind a nyugdíj, mind az egészségbiztosítási ága általánossá nem vált, a szociális gondoskodás ilyen közös teherviseléssel valósult meg. Betegség esetén ezzel összefüggésben, ha hat hét után sem várható el a munkavállaló regenerálódása és keresőképessé válása, mind a két fél rendes felmondással megszüntethette a munkaviszonyt. Ahogy a kötelező társadalombiztosítás általánossá vált, valamennyi európai államban általában fele-fele arányban viselte és viseli ma is a munkáltató és a munkavállaló a munkavállaló nyugdíj-, és egészségbiztosítását. Ez alól Nyugat-Európában Franciaország jelent annyiban kivételt, hogy ott a havi járulékok kétharmadát a munkáltató viseli, a munkavállaló csak az egyharmadát (Prugberger, 2008). ${ }^{12}$ Magyarországon és a közép-európai régió új tagállamaiban még kedvezőtlenebb a munkáltatók terhére a volt szovjet hatásra kialakult arány, mivel a járulékok háromnegyedét a munkáltatónak kell viselnie, míg a munkavállaló a járulék terheknek csak egynegyedét viseli (Károlyi-Prugberger et al., 2018:2632).

Mivel a munkáltatók a nyugat európai országokban szabadulni igyekeztek a munkavállalói biztosítás járulék-fizetéseinek e közös teherviselése alól és arra ,játszottak”, hogy az általuk foglalkoztatott dolgozók maguk intézzék és fizessék a kötelező társadalombiztosítással járó járulékterheket, csak tartós vállalkozási és/vagy megbízási szerződéssel voltak őket hajlandók foglalkoztatni. Ennél fogva jogviszonyuk formálisan vállalkozási és/vagy megbízási szerződés volt, tartalmilag azonban egyértelműen munkajogviszony. Mivel az 1970-es években Európa nyugati államaiban a szociális piacgazdaság jóléti társadalmi rendszere uralkodott, az egyes államok vagy törvényi szabályozással, vagy elvi bírósági határozattal kialakították az önfoglalkoztatásnak olyan rendszerét, amelyben, ha az önfoglalkoztatott nemcsak gazdaságilag, de egzisztenciálisan is függő helyzetbe kerül a foglalkozatójával, akkor őt munkavállalóhoz hasonló személynek kell minősíteni. Ez annyit jelent, hogy az ilyen, formálisan vállalkozónak minősülő, de függő munkát végző jogviszonyára a munkajognak valamennyi, vagy leglényegesebb munkavállalót védő individuális szabálya érvényes rá, de részben még a kollektív jogi előírások is.

A germán jogrendszerhez tartozó államok közül Németországban a Tarifsgesetz 1974. évi novellájának 12.\$-a, Ausztriában a 104/1985. sz. alatt megjelent Munka-, és Szociális bírósági törvény 54. §-a mondja ezt ki, míg Svájc esetében a Szövetségi Bíróság 118. II. 157. sz. elvi határozata, Hollandiában pedig a kantonbírák állásfoglalása. ${ }^{13}$

A frankofon-latin jogrendszerhez tartozó államok esetében a francia Code du travail tételesen meghatározza azokat a quasi vállalkozói tevékenységi köröket, amelyeknél a munkaviszonyhoz hasonlóság miatt a Code du travail valamennyi előírásait alkalmazni kell, és ugyancsak tételesen felsorolja azokat is, amelyeknél a Code du travailnek csak a munkavállalót védő leglényegesebb szabályait, mint amilyenek a munkaidőre, túlmunkára, fizetett szabadságra, munkabérre és a felmondásvédelemre vonatkozó előírások.

Hasonló szabályozás érvényesül Belgiumban is, ahol mind erről a Code du travailhoz hasonló rendszerezett jogszabálygyűjtemény szól. ${ }^{14}$ Olaszországban a Codice Civile az ipari és kereskedelmi szabadfoglalkozásúak (liberi professionisti) vállalkozási vagy megbízási, vagy pedig ne- 
Prugberger Tamás: A facere típusú szerzódések alakulása a gazdasági társasági jogalanyiság ...

vesített ügynöki szerződéssel saját kockázatra és számlára teljesítik megbízójuk megrendeléseit, megbízásait. Ezzel szemben azokat, akik megbízóik, megrendelőik kockázatára és számlájára dolgoznak a 276/2003. sz. decretum 61-69. cikkelye a Codice Civile 113. cikkelyéből levezetve munkavállalóhoz hasonló alárendelt lavoratori parasubordinato-nak minősíti és megbízóikkal szemben fennálló vitás ügyeiket a Codice civile procesuale munkaügyi vitákra vonatkozó fejezete szerint kell elbírálni.

Spanyolországban a Munka Törvénykönyvnek megfelelő Estatuto del trabajo-n túlmenően az Estatuto del trabajo autnomo (LETA) két csoportra osztja a műszaki és a szellemi szabadfoglalkozásúak csoportját. Közülük a trabajador por curenta proprie vállalkozói kockázatot visel, míg a trabajador por ajena vállalkozói kockázatot nem visel, hanem az, akinek dolgozik és aki a munkájának a gyümölcsét (frutto del trabaio) viseli. Róluk a LETA 2. fejezete szól és azok tartoznak ebbe a körbe, akik nem a saját számlájukra, hanem megbízójuk számlájára és kockázatára teljesítenek. Hogy a két kategória közül kik tartoznak ebbe a körbe, azt a munkaügyi bíróság estenként állapítja meg (Stefanescu, 2013; Kresting, 2012).

Magyarországon az ezredfordulót követő második évtized elején már előrehaladott állapotban párhuzamosan futó munkajogi és polgári jogi kodifikációs munkálatok időszakában Kiss György a Jogtudományi Közlöny 2013. évi 1. számában közzétett tanulmányában arról írt, hogy Magyarországon a nyugat-európai országokkal ellentétben hiányzik a munkavállalóhoz hasonló személy jogállásának a szabályozása, amit rendezni kellene. Mint a 2012. év közepén hatályba lépett új Munkatörvénykönyvet előkészítő kodifikációs bizottság tagja, ezt a hiányt pótolni szerette volna, mégpedig a német megoldás analógiájára olyként, hogy az új Mt. 3. §-a kimondta volna, hogy aki rendszeresen ugyanannál a foglalkoztatónál formálisan vállalkozói jogviszonyban alkalmazott igénybe vétele nélkül munkakört ellátva munkát végez, munkavállalóhoz hasonló személynek kell tekinteni és rá nézve az Mt. előírásait kell alkalmazni. Ezt a 3. §-t a 2011 júliusában kiadott Mt. javaslat tartalmazta, azonban sajnálatos módon a végleges szövegből kiiktatásra került. Ennek következtében nincs meg Magyarországon a függő munkában vállalkozási, vagy megbízási formában foglalkoztatottak számára az a védelem, ami Nyugat-Európában az ilyen módon foglalkoztatottak részére fennáll. Félő ezért, hogy ismét elindul egy olyan irányzat az egyre erőteljesebben liberalizálódó gazdaságban, hogy főleg a külföldi érdekeltségű nagyvállalkozók, ahol lehet, az önfoglalkoztatást fogják alkalmazni olyan esetben is, ahol a feladatvégzés folyamatos és függő munkavégzés jellegű. Ezért a de lege ferenda megoldás a Kiss György által elkészített Mt. javaslat szerint történő megoldás elfogadása, vagyis a jelenlegi Mt-nek a munkavállalóhoz hasonló önfoglalkoztatásra vonatkozó 3. §-ával történő kiegészítése lenne. Addig viszont, amíg erre nem kerül sor, de lege lata a bírói gyakorlatnak kellene a problémát megoldania. Ennek megfelelően azoknál a foglalkoztatottaknál, akik tartós vállalkozónak, vagy megbízottnak minősítve nem saját kockázatra és saját számlára, hanem a megbízónak, megrendelőnek alárendelve dolgoznak tartósan, vállalkozásnak vagy megbízásnak nyilvánított jogviszonyukat a Ptk. 6:92. § (2) bekezdése alapján munkaszerződést palástoló szerződésnek minősítve érvénytelennek, a palástolt munkaszerződést pedig érvényesnek szükséges minősíteni.

A magyar munkaügyi és közigazgatási bírói gyakorlat már évtizedek óta ennek megfelelően bírálja el az ilyen ügyeket. ${ }^{15}$ Akkor járna el azonban következetesen a munkaügyi bíróság, ha - az ilyen palástoló tartós vállalkozási és megbizási szerzódéssel, valóságban azonban mun- 
kaviszonynak minôsülō szerzódéssel foglalkoztatott munkavállaló által a kötelezö társadalombiztositásnak a munkáltató által fizetendö részét, amelyet a kényszervállalkozási/megbizási szerződéssel átterhelt az általa foglalkoztatott személyre - hivatalból kimondaná, hogy az így kifizetett összegek jogalap nélküli gazdagodást jelentenek, ami visszajár a munkavállalónak. Ennek megfelelően kellene eljárni akkor is, ha a foglalkoztató az ilyen munkavállalóhoz hasonló foglalkoztatottakat családtagok bevonásával áltársasági szerződés keretében foglalkoztatja. ${ }^{16}$ Innen pedig csak egy lépés, hogy a munkavállalóhoz hasonló jogviszonyokhoz közelállók alakuljanak ki egyénicsaládi és társas cégek, valamint jogi személyiséggel nem rendelkező polgári jogi társaságok és munkaközösségek között valóságos társasági és tartós vállalkozási, valamint megbízási szerződéssel. Ilyenre főleg bedolgozási formában szatelit vállalkozásként, valamint alvállalkozási jogviszonyban kerül sor.

\section{TARTÓS VAGY HUZAMOS VÁLLALKOZÁSI ÉS MEGBÍZÁSI JOGVISZONY TERMÉSZETES ÉS MÜVI (FINGÁLT) JOGALANYOK ESETÉBEN}

A piaci eladásra késztermékeket előállító, gyártó cégek az egyes alkatrészek, alkotóelemeket előállítását végző cégekkel, vállalkozókkal általában hosszú távú kooperációs szerződéseket kötnek, amelyek szatelit vállalkozásként készítik el a készterméket előállító cég részére az adott alkatrésztípusokat. Az összeszerelést végző készterméket elóállító cég és a részére alkatrészt előallító egy vagy több cég között többnyire hosszú távú kooperációs vállalkozási szerződés létesül, amely annyiban közelít a munkaviszonyhoz, hogy nem egyes megrendeléseket ad az összeszerelő üzem és fizet ki az alkatrészt előállító szatelit vállalatnak, hanem dömpingben küldi a megrendelést és havi átalányban fizet. Hasonló a helyzet a kereskedelmi beszállításnál is, amikor a kiskereskedő a nagykereskedőtől kapja meg az árut. Abban az esetben viszont, ha az egyes áruk különböző fajtájúak, minőségűek és értékűek, az esetben az átalány-ellenértékfizetés nem megoldás. Ilyenkor a történelmileg kialakult havi és/vagy évi keretmegrendelésekkel összefüggő keretelszámolásokra kerül sor, nem egyszer keretbiztosítási jelzálog alkalmazásával. Ezek a hosszútávú keretmegbízási, keretvállalkozási jogviszonyok. Az ilyen tartós együttműködésű vállalkozási és megbízási kapcsolatok kialakulása sokszínű lehet és létrejöhet a legkülönbözőbb vállalkozási formák között. Így szabad foglalkozásúak, egyéni-családi cégbejegyzett, valamint cégbejegyzés nélküli vállalkozások, valamint kisebb-nagyobb formátumú kereskedelmi társaságok között.

Kiemelkedik közülük az olyan beruházás, amely építkezéssel függ össze. A nagy beruházások esetében a legtöbbször nemcsak épületfelhúzásáról van szó, hanem ennél jóval többről. Ma már egy lakó-, vagy középület megépítésénél nemcsak egy épület egyszerű felhúzását kell a tervek alapján elvégezni, hanem olyan területek is figyelembe kell venni mint: a mélyépítési és statikai tervek alapján mélyépítészeti munkálatokat, az épületfelhúzást, továbbá a felszín alatti és felszín feletti technológiai szerelési munkákat, úgymint a vizesblokkok, a vízvezeték és az elektromos-, valamint a távfütési hálózat kialakítását.

Mindez komoly kivitelezési hálóterv kialakítását teszi szükségessé, ahol a generálkivitelezőnek a feladata egy olyan alvállalkozói hálózati rendszer kialakítása, amely minden kivitelezési munkarész-területet lefed. Nagyméretű beruházásoknál gyakori az olyan több- 
Prugberger Tamás: A facere típusú szerzódések alakulása a gazdasági társasági jogalanyiság ...

szintű lépcsőzetes háló, ahol a fő generálkivitelező több reszort generálkivitelezőt irányít és így nem egyszer kialakul a fő-, és alvállalkozók többszintű lépcsőzetes láncolata. Jóllehet, az egyes alvállalkozók feladatai elkülönülnek nemcsak egymástól, hanem a fővállalkozóétól is, mégis előfordul, hogy az alvállalkozó hasonló függésbe kerül a fővállalkozótól, mint ami a munkajogra jellemző. A fóvállalkozók az új Mt. óta legszívesebben alvállalkozóikat munkavállalóként alkalmaznák, minthogy az új Mt. munkabaleset esetén a munkáltató részére a korábbi jóval nehezebb „vis maior” alapú veszélyes üzemi kimentés helyett a sokkal könnyebb kimentési lehetőséget adó ellenőrzési körön kívüliséggel, valamint az előre nem láthatósággal mentheti ki magát vagy csökkentheti a felelősségét. Ennek a veszélye azonban valószínűleg mégsem áll fenn, mert alvállalkozóként, vagy tartós vállalkozóként, megbízottként történő kapcsolat esetén a fővállalkozónak nem kell a munkavállaló kötelező társadalombiztosításának teherviseléséhez hozzájárulniuk.

Ennél fogva nagyobb volumenű tartós fő-, és alvállalkozói kapcsolatok esetében nem valószínű, hogy a fóvállalkozó az alvállalkozójával, vagy alvállalkozóival fennálló gazdasági együttműködést függő munkaviszonyhoz hasonlóvá kívánná alakítani. Ha azonban mégis ilyenre kísérlet történne valamely fővállalkozói szerepet betöltő vállalkozás részéről bedolgozó alvállalkozójával szemben, a helyes eljárás az lenne, ha a bíróság az előbbi pontban már kifejtettek szerint megállapítaná a tartós vállalkozási és/vagy megbízási jogviszony tényleges munkaviszonyt palástoló jellegét, ami érvényes lehet akkor is, ha az önfoglalkoztató nem, vagy csak látszat gazdasági társaság vagy cég. Ez esetben a jogügyleti kapcsolatot munkaviszonyként kezelve kötelezni lenne szükséges a „quasi fóvállalkozót”, hogy a munkavállalóhoz hasonlóvá degradált alvállalkozója részére kifizesse azokat a biztosítási járulékterheket, amelyeket neki kellet volna kifizetnie munkaszerződés-kötés esetén. Ha viszont a munkavállalóhoz hasonló jogviszonnyá ledegradált quasi alvállalkozó nem egyszerű természetes személy, hanem polgári jogi társaság vagy munkaközösség, vagy ha azok valamelyike is, de cégbejegyzéssel rendelkezik, vagy gazdasági társaság (Kkt., Bt., vagy Kft., esetleg szövetkezet), abban az esetben az így leplezett tényleges tartós vállalkozási, alvállalkozási viszonyt lenne szükséges helyreállítani, mégpedig a Ptk. XXXVII. és /vagy XXXIX. fejezetébe foglaltak alapján.

Itt viszont indokolt utalni arra, hogy nemcsak tartós megbízás, hanem tartós vállalkozás esetén is a jogviszony huzamossága, tartóssága következtében a munkaviszonyhoz hasonlóan alakul a felek közötti kapcsolat. Ez mindenekelőtt az elszámolásban, a vállalkozási és/vagy a megbízási díj átalányjellegű kifizetésében, a tartós vállalkozásnál az eredménykötelmi jelleg háttérbe szorulásával és a bizalmi jelleg előtérbe kerülésében, a tartós megbízási jogviszonynál pedig bizonyos mértékig a vállalkozáshoz hasonló eredményorientáltság formájában jelenik meg. Ezt fejezi ki a megbízási jogviszony felmondását rendező 6:278. §-ánál, hogy a főszabályt jelentő bármelyik fél részéről történő bármikori felmondás mellett tartós megbízás esetén a felek megállapodhatnak a felmondás jogának a korlátozásában és abban, hogy meghatározott idő előtt rendes felmondást a másikkal szemben egyik fél sem gyakorol. A tartós megbízási szerződéseknél e szabálynak a megfogalmazása nagyon is indokolt, mivel a megbízások felvállalásával hivatásszerűen foglalkozó, ha egy vagy néhány megbízónak tartósan leköti magát, csak szűk ügyfélkört 
tud magának kialakítani. Ennél fogva, ha a tartós megbízásnál a megbízott megbízási jogviszonya hirtelen megszűnik, a munkavállalóhoz hasonlóan kerülhet kényelmetlen helyzetbe a nagyobb megélhetési jövedelmet nem biztosító kis ügyfélköre következtében. Hasonló a helyzet a tartós vállalkozás esetében is a „megrendelő” részéről a neki tartósan lekötött vállalkozóval szembeni felmondása esetében is. Ennek ellenére azonban a 6:249. §-a, a megrendelő részére a szerződés teljesítésének a megkezdése előtti bármikori elállási, a teljesítés megkezdését követően pedig a bármikori felmondási jogát biztosítja azzal, hogy a vállalkozónak a vállalkozási díj arányos részét megfizetni, valamint az elállással, illetve a felmondással okozott kárt köteles megtéríteni azzal a korláttal, hogy a kártalanítás a vállalkozói díjat nem haladhatja meg.

A megrendelői elállásnak és felmondásnak ez a szabálya a tartós vállalkozási jogviszonynál nem, vagy csak igen körülményesen alkalmazható. A 6:248. § a szerződés lehetetlenülésének a szabályait az alkalomszerű vállalkozási modellre figyelemmel az érdekkörökre tekintettel rendezi, holott a tartós vállalkozásnál az érdekkörök összecsúsznak és a munkavégzés díjazása sem pusztán eredményorientált, hanem kombináltan eredmény-, és időorientált jellegű, aminél fogva a honorárium is automatikus rendszerességgel visszatérő jellegű. Ezért itt is szükséges lenne beiktatni hasonló felmondást korlátozó szabályt, mint amit a 6:278. § a tartós megbízás esetében lehetővé tesz. Sőt megítélésem szerint mind a tartós vállalkozás, mind a tartós megbízás esetében túl kellene menni ezen és a lakásbérleti-, még inkább a munkaszerződéshez hasonlóan mind a tartós vállalkozás, mind a tartós megbízás esetében meghatározott idejü felmondási időhöz kötni a rendes felmondást.

Alkalmazni lehetne a bizalmi vagyonkezelés felmondására vonatkozó 6:326. § (1) bekezdés b.) pontját mind a két esetben, az itt szereplő három hónapos felmondási határidővel, vagy még inkább a Ptk. XLI. fejezetében foglalt közvetítői szerződés 2. alcímében szabályozott tartós válfajára vonatkozó előírásokat. A 6:296. § értelmében, ha a határozott időtartamra kötött tartós közvetítői szerződést a felek tovább folytatják, határozatlan időtartamúvá alakul át. A határozatlan időtartamút viszont a 6:297. § értelmében mindkét fél a másikkal szemben, a hónap utolsó napjára mondhatja fel, amelynél a felmondási idő az első évben egy hónap, a másodikban két hónap, a harmadikban és minden továbbiban három hónap. Ezt kellene a tartós megbízás és vállalkozás esetében is általánossá tenni. Ennek figyelembevételével indokoltnak látszana mind a 6:249., mind pedig a 6:278. §-t ennek megfelelően kiegészíteni, vagy a tartós közvetítéshez hasonlóan külön alpontba foglalni a tartós vállalkozást és a tartós megbízást.

Úgy vélem ez egy megfelelő érdekvédelmet biztosítana a kényszerből és nem saját akaratból tartós vállalkozóként és/vagy megbízási jogviszonyként munkaviszonyhoz hasonló munkakört, valamint hasonló módon alvállalkozói tevékenységet ellátó természetes személyek, csoportos munkát végző jogi személyiség nélküli társaságok, valamint jogi személyek részére. Meg kívánom jegyezni azonban, hogy nem ez lenne a tökéletes megoldás. 
Prugberger Tamás: A facere típusú szerzódések alakulása a gazdasági társasági jogalanyiság ...

\section{Az elszalasztott TÖKéletes Megoldás}

A tökéletes megoldás az lett volna, amit a Polgári Jogi Kodifikációs Főbizottság elnöke, Vékás Lajos professzor is eredetileg szeretett volna, de ami ellen kezdetben a szakszervezeti, majd pedig a munkáltatói szövetségek tiltakoztak: azaz, hogy a munkaszerződés bekerüljön a kötelmi jog különös részébe. A szakszervezetek attól tartottak, hogy ha, a munkaszerződés bekerül a Ptk-ba, az Mt. munkavállalókat védő szociális minimál-standardjai szűkülni fognak, a munkáltatói szövetségek attól féltek, hogy a szociális minimál-standardokat valóban erősen leszűkített 1972. évi Mt.-t követően elkészülő Ptk-ba ha bekerülne a munkajogviszony, tágítaná az Mt. munkavállalói érdekeket védő előírásait. Közvetlenül az új Ptk. tervezetének az országgyűléshez történt benyújtása előtt Szalma Józseffel törvényjavaslatot dolgoztam ki, melyet a Tervezetnek az egyes szerződéseket tartalmazó harmadik részébe a vállalkozási (XV. cím) és a megbízási típusú (XVI. cím) szerződések közé XVa címként, a munkavégzéssel és a szolgálattétellel összefüggő viszonyoknak megjelölve helyeztünk volna el, beleértve a magán munka-, és a közszolgálati, valamint a kollektív szerződést (Prugberger-Szalma, et. al. 2012c:16-17). Ezen annyit módosítanék, hogy helyesebb lenne XVIa. címként a megbízási típusú szerződések után elhelyezni és ezt követően pedig szintén egy újabb, XVIb. címben a tartós vállalkozási és megbízási szerződés szabályozni, amit azért lehetne együtt, mert a tartósság következtében a vállalkozási és a megbízási elemek keverednek bennük. Megbízási, bizalmi jelleg akkor is van bennük, ha tevékenység effektív eredményfelmutatási jellege dominál, de ha a bizalmi-ügyviteli jelleg áll előtérben, legtöbbször akkor is releváns az eredmény, mint motívum. Ebben az esetben, amit korábban felvetettem, vagyis a 6:249. és a 6:279. § ott megjelölt tartalmú kiegészítése szükségtelen volna, mivel az ott megjelölt felmondási - megszüntetési kiegészítések feleslegessé válnának, mivel azok lényegében egyfajta „sui generis” szerződében kerülnének rendezésre.

Ebben az esetben még markánsabban kidomborodna az a hagyomány, amelynek az eredeti szerződés csoportosítási rendszerének struktúrája a Grosschmidéknál az I. Világháborút megelőző Ptk. tervezetek, valamint a 1928-as Magánjogi Törvényjavaslat egyes szerződések csoportosítási rendszerében megfogalmazódtak és amelynek struktúrája némi módosításokkal megtalálható az 1959. évi Ptk.-ban is, de amely módosítások elhagyásával a csoportosítás rendszere „visszaközeledett” Grosschmid, valamint Szladits és körüknek sorrend-csoportosítási elképzeléseihez.

A tanulmány a NK FJH Alap támogatásával a 120158 sz. pályázat keretében készült. 


\section{Polgári Szemle · 17. évfolyam 4-6. szám}

\section{JEGYZETEK}

1 Vincenti Gusztáv (1942): A munka jogviszonyai. Munkabérleti és szolgálati szerződés. In: Szladits K. (főszerk.): Magyar magánjog, IV. kötet, Kötelmi jog különös része. Grill Károly könyvkiadó, Budapest. (lásd: 43-50.\$§ Munkabérleti, szolgálati szerz., 51.§ vállalkozás, 52.§ alkuszi ügylet, 53. § díjkitűzés (VI. fejezet); Villányi László (1942): Ügyvitel. In: Szladits K. (főszerk.): Magyar Magánjog. IV. kötet. Kötelmi jog különös része. Grill Károly könyvkiadó, Budapest, VII. Fejezet, 665-667. (54.§ Megbízás, 55. § Megbízás nélküli ügyvitel, 56.§ letét, 57.§ fogadósi felelősség). (itt feldolgozott kötelmek csoportosítva, kölcsön, vétel-csere, tartás-, életjáradék, ajándékozási szerződések, bérlet-haszonbérlet, ingyenes használat, munka jogviszony, ügyvitel). Követi a Magánjogi Törvénykönyv javaslatának (Mjt.) sorrendjét (VI-XII. címek). In: Térfy Gyula (1936): Igazságügyi zsebtörvénytár, Magánjogi Törvénykönyv javaslata. Grill Könyvkiadó, Budapest. Kisebb módosításokkal ezt vette át az 1959. IV. tv.-vel életbeléptetett első Ptk. is.

2 Nyugat-Európában kialakult gyakorlat, amit a jóléti államok vagy jogalkotási úton, vagy a szolgálati szerződés szabályaiból levezetve bírósági elvi állásfoglalásokkal, majd pedig európai gazdasági közösségi irányelvvel igyekeztek ellensúlyozni.

3 Ld. Vincenti 1. sz. jegyzetben hiv. mű 43-50. §§-ait, és a MJT. szolgálati szerződésre vonatkozó szabályait.

4 Sinzheimer, Hugo (1927): Über Grundgedanken und die Möglichkeit eines Einheitsarbeitsrechts in Deutschland. 1. Aufl. Frankfurt am Main, Europa Verlag; Aufl. Europa Verl. 1976.

${ }^{5}$ Kiss György (2013): A munkavállalóhoz hasonló személy problematikája az Európai Unióban és e szabályozás hiánya a magyar Munka Törvény Könyvében. Jogtudományi Közlöny, 1. sz. 68. évf. 1. sz. 1-14.

6 1975:XXXVII. tc. (Keresk. tv.) I. Rész VI. cím. ált., VII. c. Kkt., VIII. c. Bt., IX. c. Rt-ok, X. c. szövetk. Ugyanígy a 2013:V. tv. (új Ptk.) is.

7 Im deutschen Handelsgesetzbuch vom 10. 05. 1897. Offene Handelgesellschaft (OHG) § 105-160, Komanditgesellschaft (KG) § 161-177/a. Stile Gesellschaft 230-256. §, Aktiengesetz vom 1965 (AG), Genossenschaftsges vom 1898 (eG.) Im Zivilrecht/Wirtschaftrecht 18. Aufl. Nomos Verlag 682-694., 822., 1000. p.; Jogirodalmi rendszerbe foglalását adja Kallwas, Wolfgang: Privatrecht 16. Aufl. Verlag U. Thiemons 368-370. p. (Personengesellschaften OHG., KG., StG.), Kapitalgesellschaftten: Aktiengesellschaft (AG.), Aktiengesellschaft auf Komandit (AGK), Gesellschaft mit beschrenkte Haftung (GmbH), eingetragene Genossenschaft 370-373.

8 1988:VI. tv és 1997: CXLIV. tv. a gazdasági társaságokról, inkorporálva és szintén gazdasági társaságoknak elnevezve 2013: V. tv. (új Ptk. III. Rész X-XIV. cím és IV. Rész)

9 Sárközy Tamás (1985): A jogi személy elméletének átalakulása. Közgazdasági és Jogi Könyvkiadó, Budapest. 134-246. (a német elméletben Fabricius, Ott és Ostheim); A szövetkezeti szervezetre leképezve ld. Prugberger Tamás (1987): A jogalanyiság strukturális felfogásának megjelenése és alapproblémái a szövetkezetek gazdasági és szervezeti életében. Szövetkezeti Kutató Intézet, Közlemények (könyvsorozat), 201. Agrárinformációs Vállalat kiadása, Budapest, 38-47. (theoria ism.) és 50-80. (realizálódása a szövetkezeteknél).

10 Prugberger Tamás (2012): Magyar munka-, és közszolgálati jogi reform európai kitekintéssel. Novotni Kiadó, Miskolc. 1. kiadás, 1. nyomás, 158.; Prugberger Tamás (2013): Magyar munkajogi és közszolgálati jogi reform európai kitekintéssel. Novotni Alapítvány, Miskolc, 2. nyomás 155., 2. kiadás 1-2. nyomás 238-239.; Gyulavári Tamás (2014): A szürke állomány. Gazdaságilag függő munkavégzés a munkaviszony és az önfoglalkoztatás határán. Jogtudományi Monográfiák. 6. Pázmány Press, Budapest, 97.

11 Berki Erzsébet (1992): A munkaügyi kapcsolatok rendezésének alakulása Oroszországban az 1991-92. év fordulóján. Kereskedelmi Szemle, 6. sz. 40-42.; Scharf, Alex (1996): Gewerkschaften und sozialpartnerschaftliche Strukturen in der rusischen Föderation. WIRO - Wirtschaft und Recht in Osteuropa, 5. sz. 164-165.

12 Ld. Prugberger Tamás (2008): Az európai szociális jog vázlata. Debreceni Egyetem ÁJK. és Lícium Art Kft. közös kiadása, Debrecen, IV. (egészségbiztosítás) és V. (nyugdíjbiztosítás) fejezet (A fedezetrendszer részletes szabályainak országonkénti bemutatása).

13 Nevians, Nicole (2002): Die Arbeitnehmerahnliche Person. Dunkler et Humblot Verlag, Berlin. (D.); Wachter, Gustav (1980): Wesensmerkmale arbeitnemerahnliche Person. Schriften zum Sozial-, und Arbeitsrecht. Band. 53. Duncker \& Humblot Berlin. (A.); Portmann, Wolfgang — Stockli, Jan Fritz (2013): Schweizerisches Arbe- 


\section{Prugberger Tamás: A facere típusú szerzódések alakulása a gazdasági társasági jogalanyiság ...}

itsrecht, 3. Aufl. DIKE Verlag, Zürich - St. Gallen, 8-10.; Van Voss, Heerma G. J. J. (2006): Inleiding Nederlands Sozialrecht. Füjfte druk Boom Juristische uitgewers, Den Haag 39-40.

14 Isenberg, Sandra (2003): Arbeitsahnliche Status in Frankreich. Disposionsmanuskript, IAAEG. Universität Trier; Iura Europae. Droit du Travail - Arbeitsrecht (1993), C.H. Beck Verlag, München-Berlin/Edition technique juris chasseours, Paris I. Vol./Band. 30.00-2.3. 20-16 (B.)

15 Handó Tünde (2003): Leplezett szerződések a munkaügyi bíróságok előtt. Cég és Jog, 5. évf. 7-8. sz.

16 Prugberger Tamás - Fabók András (2012): A munkaszerződés, a szolgálati szerződés és a díjkitűzés elhatárolásának problémái a biztosítási üzletkötői szerződések tükrében. Magyar Jog, Magyar Jog, 47. évf. 12. sz.

\section{FELhaSZnÁlt irodalom}

Berki Erzsébet (1992): A munkaügyi kapcsolatok rendezésének alakulása Oroszországban az 1991-92. év fordulóján. Kereskedelmi Szemle, 6. sz. 40-42.

Gyulavári Tamás (2014): A szürke állomány. Gazdaságilag függő munkavégzés a munkaviszony és az önfoglalkoztatás határán. Fogtudományi Monográfíák. 6. Pázmány Press, Budapest, 97.

Handó Tünde (2003): Leplezett szerződések a munkaügyi bíróságok előtt. Cég és fog, 5. évf. 7-8. sz.

Isenberg, Sandra (2003): Arbeitsahnliche Status in Frankreich. Disposionsmanuskript, IAAEG. Universität Trier.

Iura Europae. Droit du Travail - Arbeitsrecht (1993), C.H. Beck Verlag, München-Berlin/Edition technique juris chasseours, Paris I. Vol./Band. 30.00-2.3. 20-16.

Kallwas, Wolfgang: Privatrecht 16. Aufl. Verlag U. Thiemons 368-370.

Kapitalgesellschaftten: Aktiengesellschaft (AG.), Aktiengesellschaft auf Komandit (AGK), Gesellschaft mit beschrenkte Haftung $(\mathrm{GmbH})$, eingetragene Genossenschaft 370-373.

Károlyi Géza - Prugberger Tamás (2018): A társadalombiztositás fedezetrendszerét érintő jogi szabályozás időszerủ kérdéseihez. Új Magyar Közigazgatás, 1. sz. 26-32.

Kersting, Anna-Lena (2012): Die arbeitnehmerähnliche Person im spanischen Arbeitsrecht. Nomos Verlag, Baden-Baden.

Kiss György (2013): A munkavállalóhoz hasonló személy problematikája az Európai Unióban és e szabályozás hiánya a magyar Munka Törvény Könyvében. Fogtudományi Közlöny, 1. sz. 68. évf. 1. sz. 1-14.

Kiss György (2020): A foglalkoztatás rugalmassága és a munkavállalói jogállás védelme. Wolters Kluwer, Budapest, 91-92. és $277-278$.

Nevians, Nicole (2002): Die Arbeitnehmerahnliche Person. Dunkler et Humblot Verlag, Berlin.

Portmann, Wolfgang - Stockli, Jan Fritz (2013): Schweizerisches Arbeitsrecht, 3. Aufl. DIKE Verlag, Zürich - St. Gallen, 8-10.

Prugberger Tamás (1987): A jogalanyiság strukturális felfogásának megjelenése és alapproblémái a szövetkezetek gazdasági és szervezeti életében. Szövetkezeti Kutató Intézet, Közlemények (könyvsorozat), 201. Agrárinformációs Vállalat kiadása, Budapest, 38-47.és 50-80.

Prugberger Tamás (1989): Belsö vagyoni és vállalkozási viszonyok az önkormányzati vállalatoknál. Szövetkezeti Kutató intézet Közlemények (könyvsorozat). 205. SZÖVORG kiadás, Budapest, 38-47. és 50-80.

Prugberger Tamás (1997): A jogalanyiság, a dologi jog és a kötelmi jog kapcsolatának funkcionális elmélete. Dissertationes Savarienses 16. Savaria Press, Szombathely, 20 - 26.

Prugberger Tamás (2008): Az európai szociális jog vázlata. Debreceni Egyetem ÁJK. és Lícium Art Kft. közös kiadása, Debrecen.

Prugberger Tamás (2012a): Magyar munka-, és közszolgálati jogi reform európai kitekintéssel. Novotni Kiadó, Miskolc. 1. kiadás, 1. nyomás, 158.

Prugberger Tamás - Fabók András (2012b): A munkaszerződés, a szolgálati szerződés és a díjkitűzés elhatárolásának problémái a biztosítási üzletkötői szerződések tükrében. Magyar Jog, Magyar fog, 47. évf. 12. sz.

Prugberger Tamás - Szalma József (2012c): A munkaviszonyra irányuló szerződés és az új Ptk. Gazdaság és fog, 10. 16-17.

Prugberger Tamás (2013): Magyar munkajogi és közszolgálati jogi reform európai kitekintéssel. Novotni Alapítvány, Miskolc, 2. nyomás 155., 2. kiadás 1-2. nyomás 238-239.

Sárközy Tamás (1985): A jogi személy elméletének átalakulása. Közgazdasági és Jogi Könyvkiadó, Budapest. 134-246.

Scharf, Alex (1996): Gewerkschaften und sozialpartnerschaftliche Strukturen in der rusischen Föderation. WIRO - Wirtschaft und 
Recht in Osteuropa, 5. sz. 164-165.

Sinzheimer, Hugo (1927): Über Grundgedanken und die Möglichkeit eines Einheitsarbeitsrechts in Deutschland. 1. Aufl. Frankfurt am Main, Europa Verlag.

Stefanescu, Alexandra (2013): Die arbeitnehmerähnliche Person in italienischen Recht. Studien zum auslandische vergleichn und internationalen Arbeitsrecht. IAAEG. Band 31. Nomos Verlag.

Térfy Gyula (1936): Igazságügyi zsebtörvénytár, Magánjogi Törvénykönyv javaslata. Grill Könyvkiadó, Budapest.

Van Voss, Heerma G. J. J. (2006): Inleiding Nederlands Sozialrecht. Füjfte druk Boom Juristische uitgewers, Den Haag 39-40.

Villányi László (1942): Ügyvitel. In: Szladits K. (főszerk.): Magyar Magánjog. IV. kötet. Kötelmi jog különös része. Grill Károly könyvkiadó, Budapest, VII. Fejezet.

Vincenti Gusztáv (1942): A munka jogviszonyai. Munkabérleti és szolgálati szerzödés. In: Szladits K. (föszerk.): Magyar magánjog, IV. kötet, Kötelmi jog különös része. Grill Károly könyvkiadó, Budapest.

Wachter, Gustav (1980): Wesensmerkmale arbeitnemerahnliche Person. Schriften zum Sozial, und Arbeitsrecht. Band. 53. Duncker \& Humblot Berlin.

Zivilrecht/Wirtschaftrecht 18. Aufl. Nomos Verlag 682-694., 822., 1000. 